\title{
A symbol - but of what? Iron Age daggers, Alessi corkscrews and anthropoid embellishment reconsidered
}

\author{
Jack Carlson*
}

An ingenious derivation for the La Tène dagger with anthropoid hilt shows how craftsmen gave an agreeable character to a working weapon. The dagger remained every bit as effective, but the splayed person on the hilt added a touch of playful luxury to the serious business of stabbing. By way of a modern anthropoid corkscrew, the author lures us away from an obsession with symbolism and encourages us to look for a more down-to-earth 'psychological functionality' in decorated objects.

Keywords: Europe, Iron Age, La Tène, dagger, anthropoid ornament

\section{Introduction}

In 1873, while digging for gravel near his home, a Mr Guyot of Salon, France, discovered a human skeleton and associated burial objects (Morel 1898: 145). Among these artefacts was a dagger with an anthropomorphic hilt (Figures $1 \& 2$ ), now in the British Museum's Morel Collection (London, British Museum: Morel Collection ML.1669; Megaw 1970: no. 228; Stead \& Rigby 1999: no. 1669). The dagger is iron, $460 \mathrm{~mm}$ long including a $345 \mathrm{~mm}$-long blade, while the hilt is bronze-coated iron. The hilt, formed from two pieces, is in the shape of a saltire, or X, with each branch of the $\mathrm{X}$ terminating in a round knob and forming the limb of a human model. The width across the arms of this anthropoid hilt is $45 \mathrm{~mm}$. The human figure's 'head', sunken between the outstretched arms, features eyebrows and oval eyes, a nose, moustache and downturned mouth, a high hairline and a ponytail.

But why was this dagger's hilt shaped like a man and decorated with human features? Current research on this and other anthropoid weapons has not addressed this question, although it is clearly of great consequence to our understanding of La Tène ritual, art, social and military hierarchy and warrior culture. Similar daggers, all dated to the La Tène period - fourth to first centuries BC - have been found as far afield as Hungary and western Ireland: the number of discovered examples is unknown, although estimates have ranged from 40 to 70 (Clarke \& Hawkes 1955: 205; Zeller 1980: 119-20; Drilhon \& Duval 1985: 308; Pleiner 1993: 49, 69; Fitzpatrick 1996: 376). While scholarship related to these weapons has concentrated almost exclusively on typology, there remains much confusion

* Institute of Archaeology, Oxford University, 36 Beaumont Street, Oxford OX1 2PG, UK (Email: john.carlson@arch.ox.ac.uk)

Received: 15 February 2011; Accepted: 4 April 2011; Revised: 18 April 2011

ANTIQUITY 85 (2011): 1312-1324

http://antiquity.ac.uk/ant/085/ant0851312.htm 


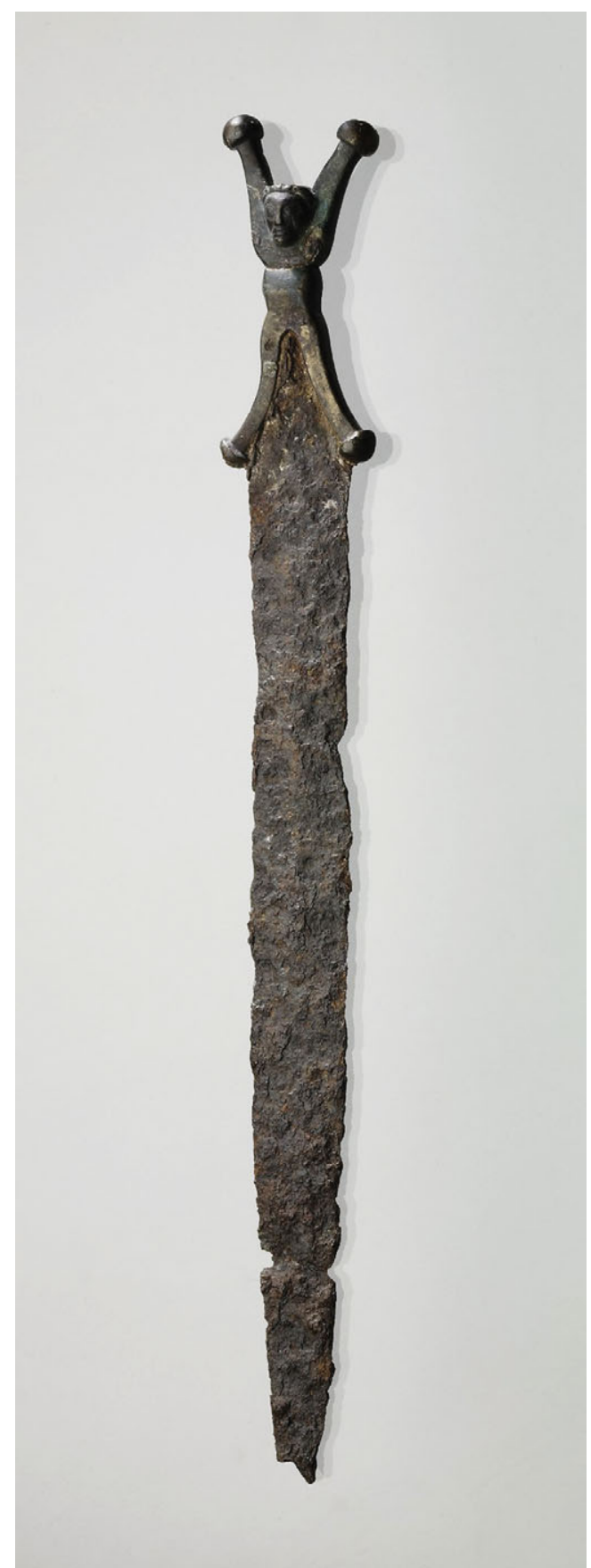

Figure 1. Anthropoid-hilt dagger from Salon, Aube, France. La Tène II, second century BC. British Museum Morel Collection ML.1669. Iron blade; bronze-coated iron hilt (C) The Trustees of the British Museum). about their functionality (Clarke \& Hawkes 1955; Petres 1979: 176; Drilhon \& Duval 1985: 185; Pleiner 1993: 49-51, 166; Megaw 2002: 408-411; Stead 2006: 72).

The idea that such daggers must have been symbols of chiefs or other high ranks and offices is pervasive (Bulard 1980: 49; Pleiner 1993: 49-51; Fitzpatrick 1996: 388; Cunliffe 1997: 233; Megaw 2002: 411) but it fails to consider context and comparanda. Traditionally, false dilemmas have been presented between the functionality of the anthropoid handle — as a religious, symbolic or funerary object and the functionality of the dagger as a weapon, and between "art for art's sake" (Megaw \& Megaw 1995: 345; Cunliffe 1997: 112; see also Aldhouse-Green 2004: xvi, 6) and a meaning related to rank or ritual (cf. Freedberg 1989: xxi-ii).

No ornament is insignificant. Ownership of an object as eye-catching as the Salon dagger, not to mention the ability to create it, surely begets a degree of prestige and respect. At the same time, the social and political functions of the anthropoid decoration are far from explicit. There is nothing to indicate that the weapon was the definite indicator of a certain rank or status (indeed there is evidence to the contrary), just as there is nothing to suggest that the Salon dagger was not a real weapon. In the broader typology of Hallstatt and La Tène weapons, anthropoid examples like the Salon dagger developed from pseudo-anthropoid weapons and antenna-daggers. Context and comparison with other objects old and new - reveal that it is both a La Tène custom and a human impulse to create such representations on utilitarian objects, especially when those objects already resemble humans or animals. In turn, a reassessment which looks beyond 


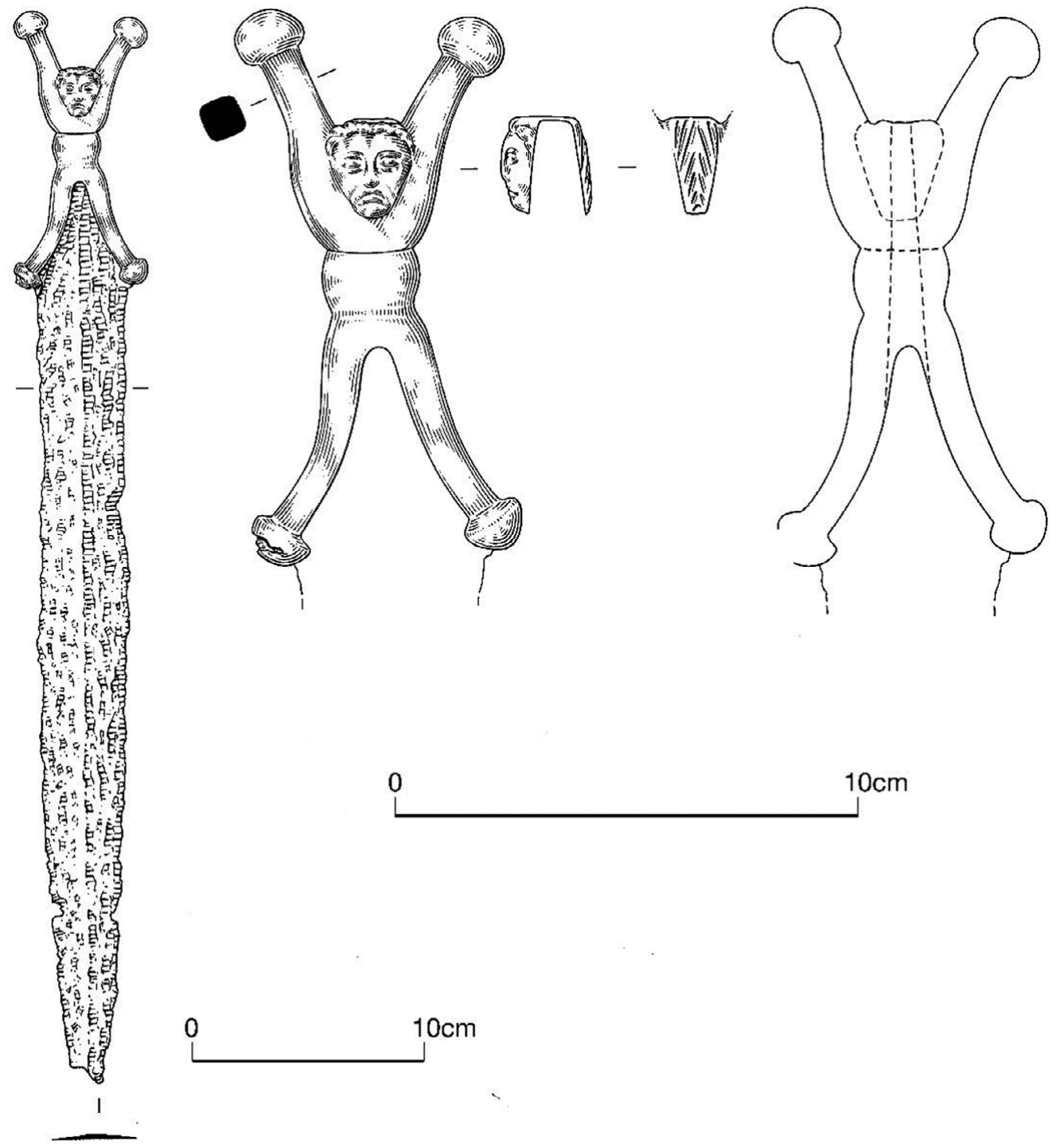

Figure 2. Anthropoid-hilt dagger from Salon, Aube, France. La Tène II, second century BC. British Museum Morel Collection ML.1669. Bronze-coated iron handle (illustration by R. Pengelly \& M. Moores from Stead \& Rigby 1999: fig. 146; (C) The Trustees of the British Museum).

conventional categories (symbol, ornament, talisman, implement) may inform the ways in which anthropoid embellishment more generally is deconstructed and understood.

To argue that anthropomorphic or zoomorphic decoration on functional objects of the La Tène period is more than mere ornament, is to state the obvious (Cunliffe 1997: 111-12). The anthropomorphic hilt served some purpose, but to take the Salon dagger as a specific emblem of rank or as a primarily symbolic object is to go a step too far. As Alfred Gell (1998: 74) has argued, the function of an object's decoration and the function of the object 
are not mutually exclusive. Gell's theory on the relationship between decoration and "the psychological functionality of artefacts" must also be considered as an alternative to hitherto unchallenged rank-related explanations for anthropoid decoration. The Salon dagger is a functional dagger and its functionality was enhanced - though not dominated — by the anthropoid hilt.

\section{The false dilemma}

Ruth and Vincent Megaw (2001: 19) introduce their book, Celtic Art, by stating that a "minimal working definition of Celtic art is that it encompasses elements of decoration beyond those necessary for functional utility". The construction 'functional utility' is somewhat contrived, perhaps because it is clear that elements of decoration may also possess utility. But the role of decoration on the Salon dagger and on La Tène objects in general has been presented as a false choice between mere ornament and specific symbolic meaning. Barry Cunliffe's discussion of the Celtic fire-dog, a wrought-iron hearth device, is a typical example (1997: 111-12): "the simple functional fire-dog['s] projecting ends were frequently decorated with enormous skill to create the spirited essence of horned bulls' heads. ... The quintessential bovine head on the fire-dog is a symbol, but of what?.. . [W] reject 'art for art's sake' as a starting point (and with it the even less acceptable 'art for art historians' sake)".

Why must it be a symbol? Zoomorphic decoration on fire-dogs was a common feature, as Cunliffe indicates; a relatively banal choice of embellishment given that the shape of the object already suggested a bovine head and, in many cases, would have required relatively little extra effort on the part of the craftsman (the highly ornate Capel Garmon fire-dog, mentioned by Aldhouse-Green [2002: 11] is exceptional). If it is granted that the bulls' heads probably made the piece more expensive, more interesting, perhaps more pleasing to use and more prestigious to display, it still seems a stretch to reach the following line of enquiry: the "bovine head on the fire-dog is a symbol, but of what?" (Cunliffe 1997: 111-12).

The same thinking has been applied to La Tène period weapons with anthropoid hilts. Cunliffe himself has speculated that "such [anthropoid] swords ... may have been an emblem of a particular social class" (1997: 233). Elsewhere, Radomír Pleiner (1993: 49_ 51) has described the daggers, including the Salon example, as "emblem[s] of rank among warriors, commanders, or chiefs", "symbols of rank" and "denot[ing] warriors of special ... rank" (see also Megaw 2002: 408, 411). Others have ascribed apotropaic or talismanic significance to the daggers, and A.P. Fitzpatrick has taken them as wholly symbolic priestly objects (Petres 1979: 176; Fitzpatrick 1996: 373, 388; Megaw \& Megaw 2001: 164; Megaw 2002: 411). The premise that such weapons must have been specific symbols, related to rank or ritual, has not accounted for the anthropoid hilts' more general social or psychological functionality. One wonders if such theories have not been influenced - directly or indirectly - by the rank-related dress daggers worn by certain officers in some modern militaries. Symbolic and apotropaic interpretations have even discounted the functionality of the Salon dagger as a weapon. While "distinguishing warriors or commanders of a certain rank" Pleiner (1993: 69) writes, "this type of sword [sic] ... could hardly have been used for fighting on the field of battle" given its small size (compared to long, slashing swords). Fitzpatrick (1996: 376) agrees that these daggers were purely symbolic. 
It is surprising that such views have gone unchallenged for so long. The approach that has been taken to the anthropoid decoration on these weapons is very different from the model proposed by Alfred Gell about the agency of decoration. While Gell (1998: 74) emphasises that there is no such thing as "mere' decoration" and that "decoration is intrinsically functional", he does not advocate that decoration should automatically be taken as symbols or emblems. With a more mature approach, Gell gives examples: a child may be more inclined to go to bed if his sheets and pillowcases are embellished with spaceships or dinosaurs; the spaceships and dinosaurs are not symbols, but the decoration enhances the bedding's functionality. Likewise, decoration on lime containers from Iatmul, New Guinea, served a general social function, enhancing the owners' prestige, but was not pegged to a specific rank or station. These sheets and lime containers are, of course, also able to "do duty" as sheets and as lime containers and certainly are not solely symbolic objects (Gell 1998: 74).

It is clear that a richer model than the binary view of function - mere decoration or emblem - may be applied to the Salon dagger. Given this theoretical background, what do the development and contexts of anthropoid-hilted weapons suggest about the Salon dagger's functionality?

\section{Development and context}

The Salon weapon was associated with a Middle La Tène non-anthropoid long sword which is now lost, and an iron scabbard (for the dagger) about which little is known except that it was entirely broken on discovery (Morel 1898: 145; Stead \& Rigby 1999: no. 1669). Based on what is known, this was not a richly furnished burial by any standard. Comparanda may give a better sense of the burial objects with which this type of weapon was associated and, perhaps, of the people who were likely to have owned them.

In their 1955 article on a La Tène anthropoid sword from Shouldham, Norfolk, UK, R.R. Clarke and C.F.C. Hawkes proposed a typology for anthropoid swords. The Salon piece has several parallels in this typology: these hilts (Clarke \& Hawkes, type E) are distinguished by the sunken head, the strongly profiled grip and median ring moulding and they have been found in Hungary, Bohemia and the Italian Alps (Clarke \& Hawkes 1955: 209-211). The only other one of this type with a known provenance comes from an assemblage which is rather different from the Salon burial: "a cremation grave at Malnate, Varese, in northern Italy near Lake Como where it was found with an iron chain belt and part of a glass armlet, characteristic of later Middle La Tène graves” (Megaw 1970: no. 228).

In fact there is wide variation in the contexts and burial goods associated with La Tène anthropoid-hilt weapons in general. Pleiner (1993: 49-51), who has taken these weapons as rank "emblems", has focused on those contexts he deems to "deserve special attention". Those are ones in which anthropoid daggers are accompanied by ornamental boar tusks, and a boat-coffin burial which included such a weapon at Chatenay-Macheron (Chaumont). Other anthropoid daggers, however, were found in relatively poorly furnished burials (Vidal 1983: 383); in some cases the weapons were not even accompanied by long swords (Stead 2006: 72). Éva f. Petres (1979: 176), writing on the Hungarian examples from the same period, notes that "in the case of [anthropoid-hilt weapons] found in cemeteries and single 
graves, the other grave-goods do not demonstrate any outstanding luxuriance". Pleiner himself (1993: 59) has commented that in this period, swords were "no longer reserved for the top men in society, but had become spread throughout the bulk of the population", and that to "distinguish between [sic] different classes of leader among the Celts ... on the basis of archaeological evidence is almost impossible in the Middle La Tène period."

Why, then, should we suppose that this, of all objects, is a symbol of a certain class of leader? A consideration of this dagger's context and that of related weapons resists such a classification and encourages new, more broad-minded readings to answer the question of why this little man was crafted on the hilt.

An understanding of the way in which these anthropoid hilts developed also suggests a more nuanced concept of functionality. For the human figure that adorned the Salon dagger was an adaptation of earlier antenna hilts and of earlier and coeval pseudo-anthropoid weapons. As decoration, an anthropomorphic hilt is fundamentally different from, for example, the lunar and solar images that are emblazoned on some La Tène period weapons (and to which Pleiner [1993: 49-51] compared the anthropoid motif). Not only is the anthropoid hilt different in terms of imagery, but it is different in that the choice to turn the handle into a little man was based on the fact that the shape of La Tène dagger handles was already suggestive of a human figure. The decoration, therefore, is more closely tied to the pure functionality of the dagger as a dagger; the little man is the hilt. Moreover, there was less creativity and additional effort required, and less freedom of choice involved in turning a pseudo-anthropoid hilt into an anthropoid hilt than, for example, in embellishing a sword with images of dragons or moons.

Late Hallstatt period (sixth to fifth centuries BC) daggers and swords from Central Europe have similar X-shaped hilts, often with a knob between the arms at the pommel end of the $\mathrm{X}$ (Sievers 1982; Figure 3). It is surely from these weapons that the later anthropoid dagger hilts developed, even if the fourth-century missing link weapons with pseudo-anthropoid hilts (i.e. without facial features) - a dagger from Ay (Senden), Bavaria (Figure 4) and a long sword $(840 \mathrm{~mm})$ from Kyšice, Plzeň in the Czech Republic — cited by R.R. Clarke and C.F.C. Hawkes (1955: 204-205) may be less clearly datable to the fourth century than has previously been suggested (Sankot 1995: 413-15). There is, of course, an abundance of La Tène pseudo-anthropoid daggers, the hilts of which were functionally and technologically the same as their Hallstatt counterparts. As daggers came to incorporate facial features on their pommel knobs, pseudo-anthropoid daggers also continued to be produced and in many cases they are exactly the same except for the lack of facial features. This development, often taken for granted, is far from trivial because the human figure was not expressly chosen to badge the objects, but rather the anthropoid hilts were a variation on those which were already felt to resemble human forms (Clarke \& Hawkes 1955: 204-205); in the same way, perhaps, that artist Pablo Picasso felt his bicycle seat to resemble the shape of a bull's head (Walton 1990: 276-7).

The final step - which in many cases, including the Salon case, only involved the addition of human features on the knob - it must be said, would not have required a large amount of extra effort on the part of the object's creator, and no additional metal. Robert Bagley (1987: 40) reminds us that in "antiquity ... in East and West alike", metal was relatively expensive and labour relatively cheap. 


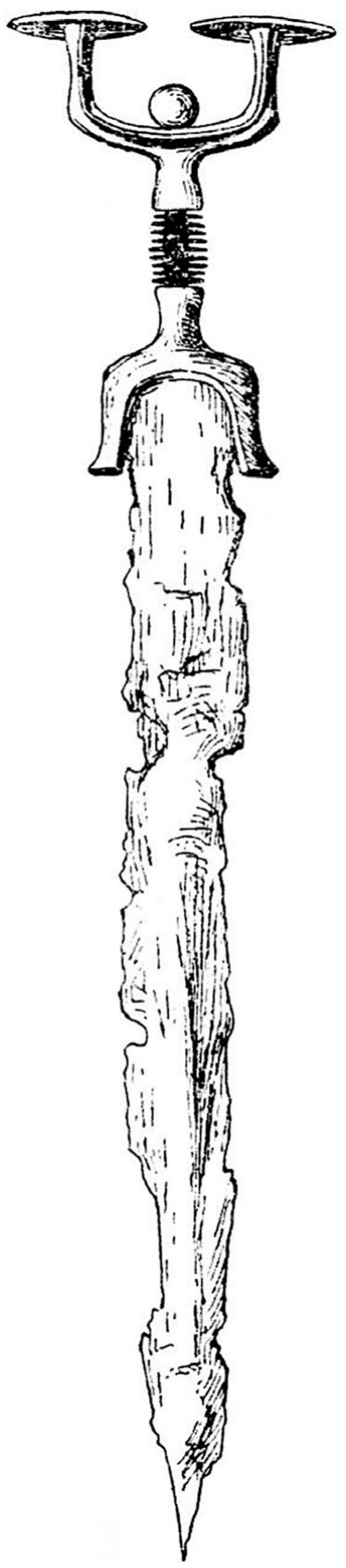

Figure 3. Antenna dagger from Hallstatt, Upper Austria, sixth-fifth centuries BC. Iron; c. $550 \mathrm{~mm}$ long; blade c. $420 \mathrm{~mm}$ long (Clarke \& Hawkes 1955: fig. 1.3; after Déchelette 1913: fig. 282.1; courtesy of the Prehistoric Society).
The Kyšice anthropoid-hilted long sword (fifth to fourth centuries BC; Clarke \& Hawkes 1955: 204-205; Sankot 1995: 413-15) also provides an important clue about the functionality of X-shaped, pseudo-anthropoid and anthropoid-hilt designs. What was the purpose of such a hilt shape? The gory truth is that it effectively enabled the warrior to stab and then draw the blade back out again; the warrior would push against the hilt figure's legs to stab, and then pull against the figure's arms to retract. The weapons to which these hilts were affixed were, of course, stabbing weapons, not - or at least not solely - slashing weapons. It is for this reason that almost all anthropoid hilts are attached to daggers and not long swords. Only early long swords, which were lighter, shorter and more sharply pointed than their later counterparts, would have use for this type of hilt (in addition to the Kyšice example, there are earlier Hallstatt pseudoanthropoid swords; Sievers 1982: 57-9). In the Middle and Late La Tène period, the long sword was modified for "slashing only" (Clarke \& Hawkes 1955: 204-205). In fact, it is probably the development of the slashing only sword which required warriors to carry an additional weapon for stabbing. Stead (2006: 72) notes briefly that anthropoid-hilt weapons may have been "subsidiary weapons" hence the presence at the Salon burial of both the Salon dagger and an accompanying long sword.

Part of the confusion, perhaps, about the functionality of the Salon dagger and other La Tène anthropoid daggers relates to a matter of vocabulary. Traditionally, these daggers have been referred to as swords or short swords (Smith 1925; Clarke \& Hawkes 1955; Megaw 1970: no. 228; Petres 1979: 176; Pleiner 1993: 49-51; Fitzpatrick 1996; Cunliffe 1997: 233; Stead 


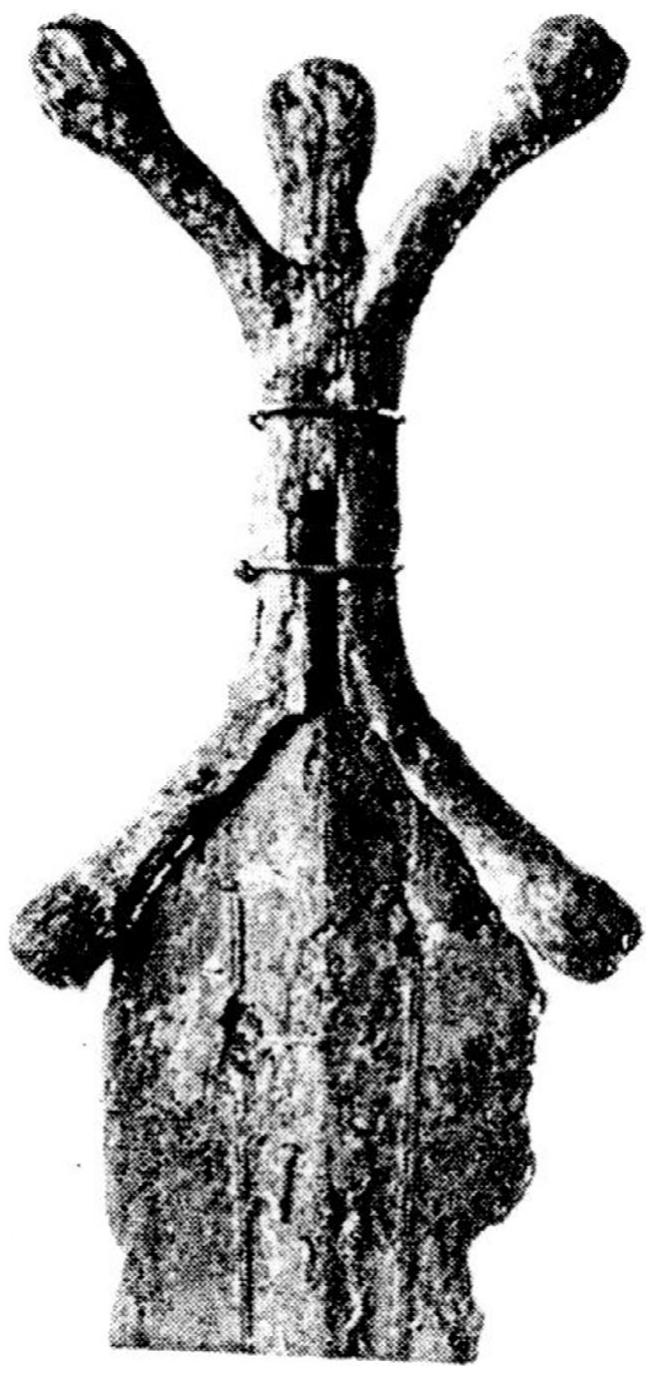

Figure 4. Pseudo-anthropoid hilt from Ay (Senden), Bavaria, fourth-century BC. Iron; hilt c. $100 \mathrm{~mm}$ long; c. 60mm across the 'arms' (Clarke \& Hawkes 1955: pl. 24.4; courtesy of the Prehistoric Society).
\& Rigby 1999: no. 1669; Jope 2000: 101; Megaw \& Megaw 2001: 164; Stead 2006: 71; see also Megaw 2002: 408). If only subconsciously, surely this word choice has impacted the ways in which scholars have conceived the weapons. While most authors, presumably working from convention, do not discuss their choice to refer to these objects as swords, A.P. Fitzpatrick (1996: 373) actually gives his rationale: "most of the weapons...are approximately $300 \mathrm{~mm}$ or more in length". But surely the question of slashing weapon or stabbing weapon is more relevant than what seems to be an arbitrary measurement. Ironically, the most careful discussion about the difficulties of such measurement-based distinctions is presented in relation to earlier, Hallstatt weaponry (Sievers 1982: 57-9). Megaw (2002: 408) justly remarks that it is "strictly incorrect to call many of [these] weapons 'swords' [when] the average length of La Tène swords is $700 \mathrm{~mm}$ ", using instead "poignards" as a loanword or, less neatly, "short swords". I.M. Stead (2006: 5), in his catalogue on British Iron Age weapons, recognises that the difference between a dagger and a short sword is the difference between stabbing and slashing weapons, but nevertheless sets "arbitrary limits" of $305 \mathrm{~mm}$ for the longest dagger blade and $320 \mathrm{~mm}$ for the blade of the "shortest short sword"; these parameters would place the Salon dagger (with a blade length of $345 \mathrm{~mm}$ ) just inside the sword category. As slashing swords, however, these

objects would be fairly useless and Pleiner (1993: 69) concludes that "this type of sword [sic]... could hardly have been used for fighting". As daggers, however, they would have been fully functional thanks, in part, to the design of their grips, some of which are worn "by use" (Smith 1925: 59-60).

Considerations of context and development confirm that the anthropoid shape of the Salon dagger's hilt had much to do with the weapon's stabbing efficacy and little to do with the specific symbolic functionality of a human figure. But why make the anthropomorphism of these dagger hilts explicit by adding human facial features? 


\section{Psychological functionality}

Alfred Gell (1998: 74) contended that "the world is filled with decorated objects because decoration is often essential to the psychological functionality of artefacts, which cannot be dissociated from the other types of functionality they possess". But just as the anthropoid hilt was, as mentioned above, a fundamentally different sort of decoration from inlaid astral images on La Tène weapons it is, of course, also different from Gell's 'psychological functionality' examples: decorated Iatmul lime-containers and children's bedsheets embellished with dinosaurs or spaceships. If, many centuries from now, an archaeologist discovers early twenty-first-century children's bedding, she might rightly wonder why images of dinosaurs and spaceships, of all things, were chosen to adorn the textile. But we need not even ask such questions about the Salon hilt: why a human? Why did the designers of this object choose this motif? Why are his arms and legs outstretched? It is a symbol, but what does it mean? The grip was made into a model human with outstretched limbs because that is what effective dagger handles looked like anyway. This was the most obvious, straightforward way of making the La Tène dagger fancier; more obvious, certainly, than the other methods of embellishment - chagrinage; engraved combatant dragons on the blade; plant motifs - employed by those "major creators of Celtic art" (Megaw \& Megaw 2001: 126), the iron- and bronzesmiths.

One very simple rationale for at least part of the Salon dagger's functionality, and yet one which has scarcely been mentioned, if at all, in scholarship on anthropoid weapons, is that it was a luxury object. Many warriors owned daggers, but not all daggers were created equal. We need not search more deeply to understand the anthropoid hilt than we do to understand decorated Iatmul lime-containers. The anthropoid hilt was an adaptation of a relatively commonplace object, and it was modified such that its increased complexity was clear to the observer. Like any luxury item, it enhanced its owner's prestige in a general way and, in turn, was likely to have had a psychological impact on the owner or bearer of the dagger, whether the owner lived in Salon, in Ireland or in the Carpathian Basin, and whether the owner's burial was rich or sparse. While still related to social standing, this notion is clearly very different from the rank symbol interpretations.

One modern example of a functional object for which an anthropoid luxury version exists is the wing corkscrew (Figure 5). I remember thinking, as a child, that these devices looked like little men; one could make their arms flap by moving their heads up and down. I am not, of course, the only person to have thought so; since 1994, one of Italian utensil company Alessi's best-selling products has been an explicitly anthropoid version of the wing corkscrew, designed by Alessandro Mendini (Figure 6). One might also compare the anthropomorphic hilts to pouring spouts decorated as birds' mouths - a global phenomenon in both the ancient and modern world. As these objects demonstrate, there is a universal impulse to see anthropomorphic and zoomorphic shapes in objects, and to make that zoo- or anthropomorphism explicit.

The Alessi corkscrew is a luxury item and surely these objects are sometimes conversationstarters at parties, while at other times guests may simply take note of the owner's tastes and of the affluence which ownership of such an object implies. But ownership of the Alessi corkscrew is not strictly limited to any certain group of people. And, most clearly, Anna G., 


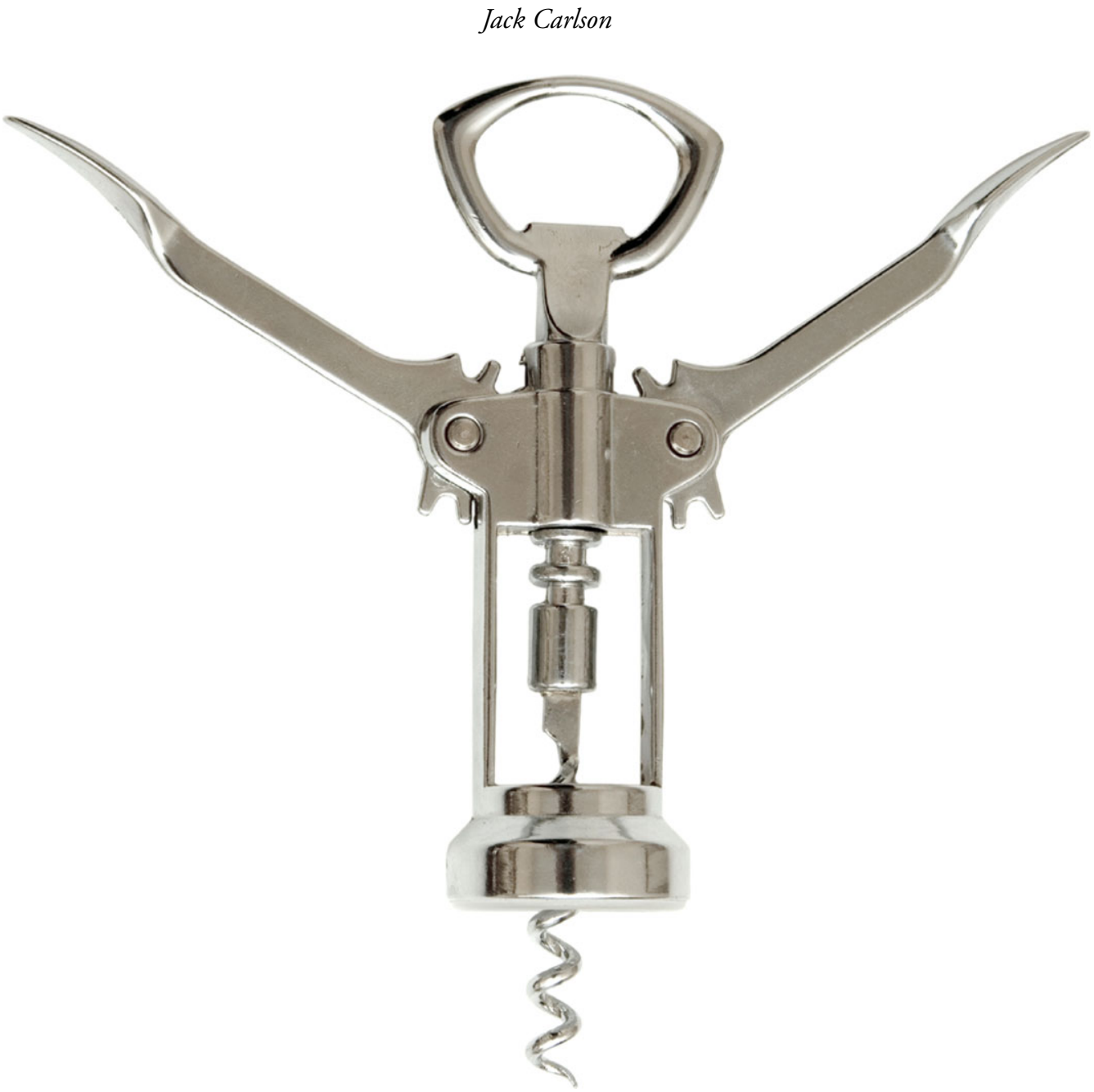

Figure 5. A household wing corkscrew, twentieth century, chrome (C) iStockPhoto.com/Nikolay Titov).

as the anthropoid corkscrew has cheerfully been christened by its designer, is not a symbol or emblem of anything at all. If, rather than adding facial features and hair to a conventional corkscrew design - to make the corkscrew truly anthropomorphic - the creators of this object had instead emblazoned the device with an heraldic badge, a moon or a dragon, or fashioned the head of the corkscrew in the shape of a cross or a fleur-de-lis, then many more questions would need asking and answering.

Needless to say, the anthropoid version of the corkscrew is also a working corkscrew: if it were not, how could it function as an index of taste or wealth? It would also lose its psychological functionality if it could not work as a corkscrew. Any pleasure derived from using, holding or displaying the corkscrew, or from seeing it in action, must also be considered as part of the utensil's functionality.

While it is true that we need not search too deeply for the meaning of the figure on the Salon hilt (just as we do not in the case of the Alessi corkscrew), it surely had other psychological effects beyond the social esteem associated with owning, wearing and bearing 
A symbol — but of what? Iron Age daggers, Alessi corkscrews and anthropoid embellishment reconsidered

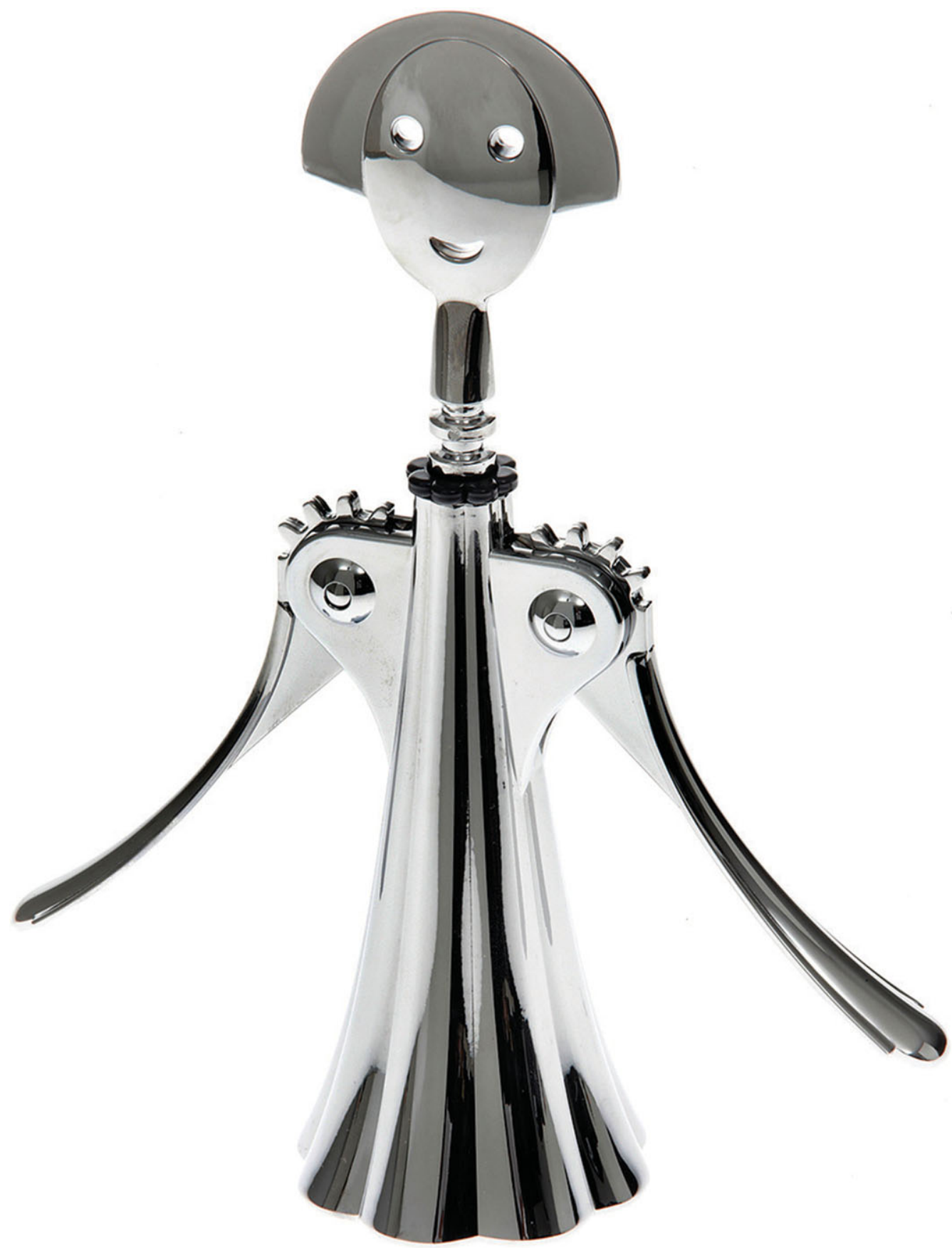

Figure 6. An anthropoid household wing corkscrew designed by Alessandro Mendini and produced by Alessi S.p.A., twentieth century, chrome-plated zamak (courtesy of Urban Attitude). 
such a weapon. This is not to say that the anthropoid hilt made the act of stabbing enjoyable in the same way that the Alessi corkscrew may well be a source of pleasure for its owners. When one is relying on an object to be able to save one's life, one wants to know that the object is as finely crafted as possible and the inclusion of human features would have clearly reflected the smith's attention to detail. In the same way that a warrior might derive a psychological benefit by entering battle with well-polished armour, boots or weaponry, so too might the Salon warrior have benefited from fighting with a showy dagger. A similar comparison may be made between the Salon dagger and modern military aircraft, bombs and missiles decorated with a shark's face motif on their noses. If, in battle, our Salon man found himself engaged in "the ancient and European tradition of dagger fighting" (Clarke \& Hawkes 1955: 204), the warrior with the fancy, anthropoid hilt may have had a psychological edge. Such theories are not far-fetched and, in a complete consideration of the daggers' functionality, must be taken into account; by way of comparison: in a recent psychological study, it was proven that the fighter wearing red benefits from a psychological advantage and has a significantly greater chance of winning in boxing and other combat sports (Hill \& Barton 2005: 293).

The possibility that the anthropomorphic nature of these hilts may have helped La Tène warriors connect with their weapons must also be considered. As Kendall Walton (1990: 11, 51, 276-7) describes, representations, including toys, paintings, plays and the bull's head Picasso made from a bicycle seat, inevitably invite their viewers and users into a game of make believe. Modern US marines and soldiers name their rifles which, of course, are not even anthropomorphic so it is not such a stretch to imagine warriors of the La Tène period naming their anthropoid daggers. We may never know if they did, but this is the type of rich consideration of functionality which comparison is often able to bring to light and which the Salon dagger and other anthropoid weapons deserve.

Anthropoid objects have been created and used in civilisations ancient and modern. They provoke a range of responses and associations: they are whimsical, dazzling and uncanny (unheimlich) and they resist classification as art, symbol or implement. This reconsideration of the Salon hilt - as a form inspired by function and, inexorably, possessing a dynamic social and psychological functionality of its own - may find application in our interpretations not only of other La Tène objects, but of archaeological artefacts more broadly. There is a temptation among archaeologists to declare that ancient objects which the modern world has long treated as art were more significant — often symbolically significant than mere ornament in the societies which created them. This is at once a truism and a misleading assumption. Anthropoid hilts very likely came about not because of some mysterious political or religious semiotics on which we can only speculate, but because earlier dagger hilts, in order to function properly, happened to look a little like men with outstretched limbs. But decoration, especially when it is representational, intrinsically affects the ways in which useful objects are useful (Walton 1990: 51; Gell 1998: 74). Interpretations of anthropomorphic and zoomorphic embellishment — whether that embellishment occurs on Iron Age weapons and fire-dogs or on twenty-first-century corkscrews - must begin with this understanding and not with the straw man proposition that such images are art for art's sake. By considering and actively applying — through comparison if it is helpful — the notion of an artefact's psychological functionality, it is possible to overcome 
perpetuated assumptions (emblem of rank) and scholarly impediments (a symbol, but of what?).

\section{References}

Aldhouse-Green, M. 2002. Any old iron! Symbolism and ironworking in Iron Age Europe, in M. Aldhouse-Green \& P. Webster (ed.) Artefacts and archaeology: aspects of the Celtic and Roman world: 8-19. Cardiff: University of Wales Press.

- 2004. An archaeology of images: iconology and cosmology in Iron Age and Roman Europe. London: Routledge.

Bagley, R. 1987. Ancient Chinese bronzes from the Arthur M. Sackler collections. Volume 1: Shang ritual bronzes in the Arthur M. Sackler collections. Washington (DC): Arthur M. Sackler Foundation; Cambridge: Arthur M. Sackler Museum \& Harvard University.

Bulard, A. 1980. Sur deux poignards de la fin de l'époque de La Tène. Etudes Celtiques 17: 33-49.

Clarke, R.R. \& C.F.C. HaWkes. 1955. An iron anthropoid sword from Shouldham, Norfolk, with related continental and British weapons. Proceedings of the Prehistoric Society 21: 198-227.

Cunliffe, B. 1997. The ancient Celts. Oxford: Oxford University Press.

DéCheletTe, J. 1913. Manuel d'archéologie préhistorique, celtique et gallo-romaine. Volume 2: archéologie celtique ou protohistorique. Paris: Picard.

Drilhon, F. \& A. Duval. 1985. Méthode d'étude des poignards anthropoïdes de La Tène, in L.

Bonnamour, A. Duval \& J-P. Guillamet (ed.) Les âges du fer dans la vallée de la Saône: VII $-I^{e r}$ siècles avant notre ère; Paléométallurgie du bronze à l'âge du fer: actes du VII colloque de l'Association Française pour l'Etude de l'Âge du Fer, Rully, 12-15 mai 1983: 299-308. Paris: CNRS.

FITZPATRICK, A.P. 1996. Night and day: the symbolism of astral signs on later Iron Age anthropomorphic short swords. Proceedings of the Prehistoric Society 62: 373-98.

FREEDBERG, D. 1989. The power of images: studies in the history and theory of response. Chicago (IL): University of Chicago Press.

GeLL, A. 1998. Art and agency: an anthropological theory. Oxford: Oxford University Press.

Hill, R.A. \& R.A. BARTON. 2005. Psychology: red enhances human performance in contests. Nature 435: 239.

Jope, E.M. 2000. Early Celtic art in the British Isles. Oxford: Clarendon Press.

MEgaW, J.V.S. 1970. Art of the European Iron Age: a study of the elusive image. Bath: Adams \& Dart.
- 2002. A late La Tène anthropoid gripped sword in New York, in K. Kuzmová, K. Pieta \& J. Rajtár (ed.) Zwischen Rom und dem Barbaricum: Festschrift für Titus Kolník zum 70. Geburtstag (Archaeologica Slovaca Monographiae 5): 407-418. Nitra: Archäologisches Institut der Slowakischen Akademie der Wissenschaften.

Megaw, J.V.S. \& M.R. Megaw. 1995. The nature and function of Celtic art, in M.J. Green (ed.) The Celtic world: 345-75. London: Routledge.

- 2001. Celtic art: from its beginnings to the Book of Kells. London: Thames \& Hudson.

MOREL, L. 1898. La Champagne souterrain: matériaux et documents ou résultats de trente-cinq années de fouilles archéologiques dans la Marne. Reims: Matot-Braine.

PETRES, É.F. 1979. Some remarks on anthropoid and pseudo-anthropoid hilted daggers in Hungary, in P-M. Duval \& V. Kruta (ed.) Les mouvements celtiques $d u V^{e}$ au $I^{e r}$ siècle avant notre ère: actes $d u$ XXVIII colloque organiseé à l'occasion du IX Congreś international des sciences prehistoriques et protohistoriques, Nice, le 19 septembre 1976: 171-8. Paris: CNRS.

Pleiner, R. 1993. The Celtic sword. Oxford: Clarendon Press.

SANKOT, P. 1995. Les épées pseudo-anthropoïdes de Bohême, in J-J. Charpy (ed.) L'Europe celtique du $V^{e}$ au III siècle avant J.-C.: contacts, échanges et mouvements de populations (Mémoires de la Société Archéologique Champenoise 9): 413-22. Sceaux: Kronos.

SIEVERS, S. 1982. Die mitteleuropäischen Hallstattdolche (Prähistorische Bronzefunde 6.6). München: Beck.

SMITH, R. 1925. A guide to antiquities of the Early Iron Age in the Department of British and Mediaeval Antiquities. London: British Museum.

STEAD, I.M. 2006. British Iron Age swords and scabbards. London: British Museum.

STEAD, I.M. \& V. RigBY. 1999. Iron Age antiquities from Champagne in the British Museum: the Morel Collection. London: British Museum.

VIDAL, M. 1983. Poignard anthropoïde de la nécropole Saint-Roch à Toulouse (Haute-Garonne). Revue archéologique de Narbonnaise 16: 377-83.

WaLton, K.L. 1990. Mimesis as make-believe: on the foundations of the representational arts. Cambridge (MA): Harvard University Press.

ZELLER, K.W. 1980. Kriegswesen und Bewaffnung der Kelten, in L. Pauli (ed.) Die Kelten in Mitteleuropa: Kultur, Kunt, Wirtschaft: 111-32. Salzburg: Amt der Salzburger Landesregierung, Kulturabteilung. 